\title{
An Analysis of Artistic form and Musical Perspective of Romantic Era Music
}

\section{Herry Rizal Djahwasi, Zaharul Lailiddin Saidon}

To Link this Article: http://dx.doi.org/10.6007/IJARBSS/v11-i11/11322 DOI:10.6007/IJARBSS/v11-i11//11322

Received: 12 September 2021, Revised: 08 October 2021, Accepted: 30 October 2021

Published Online: 10 November 2021

In-Text Citation: (Djahwasi \& Saidon, 2021)

To Cite this Article: Djahwasi, H. R., \& Saidon, Z. L. (2021). An Analysis of Artistic form and Musical Perspective of Romantic Era Music. International Journal of Academic Research in Business and Social Sciences, 11(11), 771-782.

\section{Copyright: @ 2021 The Author(s)}

Published by Human Resource Management Academic Research Society (www.hrmars.com)

This article is published under the Creative Commons Attribution (CC BY 4.0) license. Anyone may reproduce, distribute, translate and create derivative works of this article (for both commercial and non-commercial purposes), subject to full attribution to the original publication and authors. The full terms of this license may be seen at: http://creativecommons.org/licences/by/4.0/legalcode

Full Terms \& Conditions of access and use can be found at http://hrmars.com/index.php/pages/detail/publication-ethics 


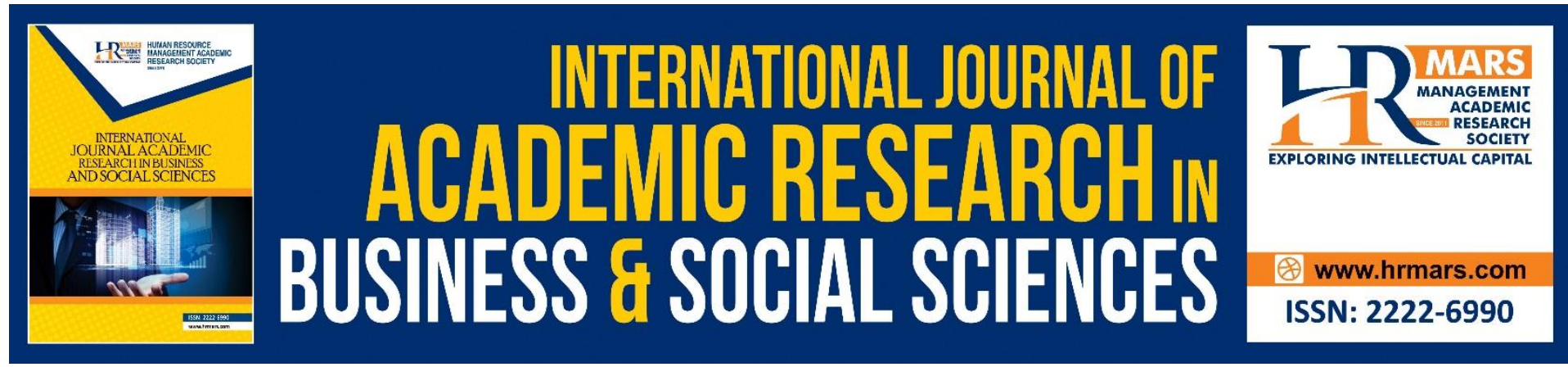

\title{
An Analysis of Artistic form and Musical Perspective of Romantic Era Music
}

\author{
Herry Rizal Djahwasi, Zaharul Lailiddin Saidon \\ Department of Music and Music Education, Faculty of Music and Performing Arts, Sultan \\ Idris Education University, Malaysia
}

\begin{abstract}
Artistic freedom, the influence of the French revolution and the massive development of musicology had a significant influence on the variety and diversity of compositional forms in the Romantic era. However, many features of the performance style in romantic period require a deeper understanding, especially related to expression features from performer's perspective. This article examines a number of aspects that correlate with the style of performance in the romantic era. There are three objectives in this article. The first is to correlate compositional works in the romantic era that illustrate the symbiotic relationship between artistic forms and non-musical ideas, especially socio-political sentiments. The second is to review the role of musicology and philosophical perspective in building a structure of knowledge in music performance. The third is to characterize the performance style in romantic era. The methodology of this research is carried out based on a literature study. This article is part of an ongoing research with the title Artistic research: Characterization my classical guitar method based on two selected repertoires. Through this article, it is hoped that the understanding of the influence of musical and extra-musical aspects on the romantic era's performance style can be clarified.
\end{abstract}

Keyword: History of Romantic Era, Performance Style, French Revolution Influence.

\section{Introduction}

In understanding the fundamental differences between Romantic and pre-Romantic music takes much perspective. There is fundamental difference between the time period of romantic in humanistic periodisation and music periodisation. The beginning of the romantic era is associated by music historians with the death of Haydn 1809 or Schubert 1828. Meanwhile, humanistic historian includes the social and political historians place the French war of 1789 as the beginning of the romantic era (Burkholder et.al., 2019). Historians of literature and visual arts have followed the socio-political periodization more closely than music historians (Samson, 2014).

In our opinion, the music historians attribute the beginning of the romantic era to the death of Haydn in 1809 or Schubert in 1828 which is broadly an affirmation of the transition from the Viennese circle style of composition to a new style of composition. However, the history of music in the romantic era is not only related to the artistic form. The French revolution is 
clearly a thesis that no history of nineteenth-century music can afford to ignore. A number of transformations of thought about music that occur are also noteworthy. In this era, the musicology was proclaimed as a discipline (Kursell, 2015; Beard and Gloag, 2016) and the massiveness of the philosopher's attention related to music. Particularly, philosophy of absolute music as echoed by Wagner emerged in this era (Bonds, 2017). The conclusion that can be drawn, the history of nineteenth-century music, then, is a history of works, composers and performers; of traditions, media and styles; of institutions, ideas and responses (Samson, 2014).

The present article is born out of three premises. The first is to correlate compositional works in the romantic era that illustrate the symbiotic relationship between artistic forms and nonmusical ideas, especially socio-political sentiments. The second is to review the role of musicology and philosophical perspective in building a structure of knowledge in music performance. The third is to characterize the performance style in romantic era.

\section{The Influence of French Revolution in Compositional Works}

We found something interesting about the social and political connection of the romantic era with the role of the composer. The waning of the aristocracy in the French revolution had an impact on the composer's existence. Frisch (2013); Bonds (2013) presents a comparison between the existence of composers in classical and romantic eras. In the classical era, the composer served in aristocratic circles as Joseph Haydn spent most of his career in service to the aristocratic Esterházy family. Wolfgang Mozart was also supported by patrons. So that it is inevitable that composers in the classical era are seen as craftsmen who provide goods made to order. In contrast, the romantic composers work independently as professionals who have the composer had taken on the aura of a divinely inspired creator, a demigod.

Furthermore, the historians in expressing the history of music in romantic era have attempted to reveal not only the notes of a composition, but also the spirit embodied in the notes (Salop, 1965). This makes perfect sense in discussion of the history of romantic era, we have found in a number of literatures that is very inspiring.

Regarding the influence of French revolution in compositional works, we will introduce two compositions which are full of inspirational stories. The first story contains Beethoven's symphony No. 3 which is known as the Eroica symphony. Meanwhile, the second story refers to Chopin's composition in the form of the mazurkas and polonaises. Particularly, A major Polonaise, op. 40.

This spirit of the French revolution was translated in a very sophisticated way by Beethoven in symphony No. 3 in 1806. Burkholder et. al (2019) describes that Beethoven was steeped in Enlightenment ideals: absorbed the music of Haydn and Mozart: was affected by the French Revolution: idealized and then, disillusioned by Napoleon. Beethoven in symphony No. 3 as an act of artistic liberation (Bond, 2013) and emphasizes freedom of expression (Kamien, 2015). Based on the artistic form and aesthetic perspective which is driven by the sociopolitics of the French revolution, I believe this composition is quite worthy of being a monument to the opening of the romantic era. 
Beethoven composed Symphony No. 3 in E- flat Major, Op. 55 around 1803 and the first publication were in 1806. Currently, Beethoven's symphony no. 3 is better known as the Eroica symphony. Kinderman $(2020 ;$ p. 87) describes in detail that the first symphony rehearsal took place at the Lobkowitz Palace on 9 June 1804; The first public show occurred at theatre an der Wien on April 7, 1805.

The spirit of the French revolution in 1789-1815 that was kindled by Napoleon Bonaparte inspired Beethoven to perpetuate it in the form of a symphony. Initially, this symphony was dedicated to Napoleon Bonaparte whom he admired as a hero of the French Republic (Burkholder et.all.2019). The Eroica symphony was a portrait of Bonaparte, which is also a portrait of Beethoven himself (Grove, 1896).

However, according to Beethoven pupil Ferdinand Ries, when Napoleon had proclaimed himself emperor of the French, Beethoven angrily tore up the title pages (Burkholder et.all.2019). He disappointed when his idol proved to be an ambitious ruler on his way to becoming a tyrant. Furthermore, he later wrote on the title page "Heroic Symphony composed to celebrate the memory of a great man." (Kamien, 2015).

As a composition, Eroica has a unique structure. The form and music structure of symphony No.3 is unprecedented design, and its powerful emotional impact have continually fascinated critic (Sipe, 1998). According to Grove (1896; p.50), March in the second movement is distinct innovation on the previous custom, the title of Scherzo in third movement here used in the symphony for the first time and in the finale, the daring and romance which pervade the movement under so much strictness of form. Artistically, the Eroica is a landmark in music history (Kamien, 2015).

The symphony creation began with the final, whose musical material is taken from Piano Variations op. 35 and mythical symbolism that originates from the ballet of Prometheus (Kinderman, 2020). Sipe, (1998) narrates the Eroica symphony as an epic, in which battle-like opening movement, the borrowings from French revolutionary celebration on funeral march, the third movement id symbolizing a young soldier in the scherzo, and the allusion to the Ballet of the creatures of Prometheus in the finale all have special Napoleonic significance. I come to the end of Beethoven's Eroica symphony story with my conclusion that this composition represents an evocative landscape that reflects Beethoven's self-conscious artistic mission.

Frederic Francois Chopin's A Major Polonaise, op. 40 is the second story which compositional works relate to the social and political sentiment in romantic era. Frederic Francois Chopin (1810-1849) a composer and pianist from Poland with his work A major Polonaise, op. 40. In the history of music, the first quarter of the nineteenth century is sometimes called the "Beethoven era" or the "Rossini era," because these characters of both composers are considered the most representative (Frisch, 2013). According to Rosen (1971), Beethoven's death in 1827 must have provided a sense of freedom for the composer who was born nearly two decades earlier. But that is not to say Chopin was intimidated by Beethoven's development of new stylistic tendencies. 
Chopin is not only known as a composer, but also a virtuoso pianist. Chopin did not make a revolution as Bach, Haydn, Mozart or Beethoven demonstrated. But the interesting thing is, he shows his own identity in music. Particularly, Chopin is an expert at perfecting and delivering his music in detail (Gołab, 2014). I found something interesting in the way he presented his nationalistic identity to his music. A number of his works in polonaise and mazurka are symbols of Chopin conveying his identity as a Polish that he wrote while living in Paris as part of the Polish exile community (Bonds, 2017). But, in the entire Polish element pervades, the polonaises dances are the most Polish of his works (Huneker,1966; p.289).

In the romantic era, there is the trend for romantic composers to deliberately create music with a certain national identity, using folk songs, dances, legends, and the history of their homeland (Kamien, 2015). In the midst of the political upheaval that occurred in Poland at that time, Chopin voiced two big dimensions of nationalism. The first, he showed to the main focus for reaffirmation of culture, and national pride (Thomas, 2007). The second, he demonstrated the authenticity of Chopin's commitment to Poland Chopin's (Samson, 2007).

According to McKee (2017; p. 187-188), considering the "universal" popularity of the minuet, it is remarkable that Poland in the eighteenth century was the only country in all of Western and Central Europe that did not use the minuet as the emblem of its ruling class or as an example for polite behaviour. Polonaise serves these functions; it also represents the Polish nation, its people, its customs, and its history. Chopin wrote at least 23 polonaises for piano solo.

In an article on Polish dance types, poet Kazimierz Brodzi'nski (1791-1835) as quoted by Mckee (2017; p.190) wrote:

As far as Polish dance, the polonaise can be called a serious knightly dance; the French minuet is a dance of an elegant court and educated society [...] The polonaise is equal to the minuet as a noble dance, but has more freedom and less theatre [...] It does not express any sentiment of passion, but seems to be a triumphant procession, and the expression of serene noble sentiments

Among the Polonaises he wrote, the Polonaise Op. 40 has a very inspiring spirit. Chopin's polonaise op.40 was composed between 1838 for Polonaise in A Major and 1839 for in C Minor (Gołab, 2014). Later, Chopin's Polonaise Op. 40 became the pride of the Polish people, who after regaining national independence after World War I, Radio Poland adopted the idea of opening up Op. 40 No. 1 as its national call signal (Thomas, 2007).

Even the story runs after, regarding Chopin's Polonaise, op. 40, Rubinstein narrated No.1 in A major is a picture of Poland's greatness, meanwhile in C minor No.2 as its companion is off Poland's downfall (Huneker,1966). Artistically, the Polonaise Op. 40 is notation Chopin's loudest work: the music never drops below $f$ and reaches the level of fff four times. The massive sound of Op. 40, No. 1 is not only a result of its extreme dynamics but also of a chordal texture based on an underlying five-voice framework. Meanwhile, In the C Minor, Op. 40, No. 2, Chopin introduces tragic elements and distorts basic features of the heroic polonaise to the point of failure (McKee, 2017; p.89). Closing Chopin's Polonaise, op. 40 I am impressed by 
what Samson (2007) who revealed that Chopin's work will indeed be a useful case study in the history of taste, and perhaps also the history of taste-creating institutions.

The two stories above illustrate that the nineteenth century brought the bloom of romance, when composers began to individuate work as an expression of their passion (Schmalfeldt, 2011). So, it is not surprising, in revealing the history of music in the romantic era, music historians argue that music in the romantic era has a variety of artistic forms. This view has two basic arguments, namely aesthetic and artistic.

In romantic era, aesthetically, the expressions embodied in music works were formed by the Idea of originality and emotional subjectivity (Bonds, 2013). Meanwhile, artistically, Kamien (2015) states that romantic music is so diverse, much so efforts to generalize it has a tendency to be misleading. In one side, some romantic composers, such as Mendelssohn, and Brahms or the classical guitar composers such as Fernando Sor and Mauro Giuliani, created works that were firmly rooted in classical tradition. But in other side, composers, such as Berlioz, Liszt, and Wagner were more revolutionary in the term of harmony, intensity and orchestration.

\section{The role of musicology and philosophical perspective in building a structure of knowledge in classical music performance}

The intimacy between ideas and music, however, is very beneficial for the development of music paradigm both in terms of thought and in terms of artistic form. According to Huneker (1966) in romantic era, there are so many things between two paradigms in music of which they alone can be the judges each other. This situation triggered composers in developing new styles in music works that was novelty, individual, evocative, spectacular, nationalist, exotic, or in some other way distinctive yet attractive.

The development of the astonishing diversity of musical cultures in the ninth tenth century prompted scholars to apply evolutionary thinking to music (Cook, 1992). The affirmation of the meaning of instrumental music is one of the things that is highlighted by the concept of thought in the era of romanticism. There is an awareness that instrumental music provides an unlimited platform of expression. E.T.A. Hoffmann in 1813 as quoted by Frisch (2013) expressed this view clearly: "When we speak of music as an independent art, should we not always restrict our meaning to instrumental music.

Meanwhile, Schopenhauer (1906; p.448-449) states that music expresses "the will its self" for the very reason that it is "the language of the feelings" and of the passions rather than of verbal concepts. "This is why the effect of music is so much more powerful and penetrating than that of the other arts, for they speak only of shadows, but music speaks of the thing itself (Schopenhauer, 1906, p. 336; Borisovich \& Anatolevich, 2016).

One of the growing passions also in romantic era has to do with writing music history. According to Stevens, (1980), although music historiography does not appear to be a branch that deserves serious consideration, however, there are a number of historians who specialize in writing related to music history such as Giovanni Battista Martini (1706-1784), Antonio Eximeno (1729-1808), Charles Burney (1726-1814), John Hawkins (1719-1789) Johann Nikolaus Forkel (1749-1818), August Wilhelm Ambros (1816-1876) and François-Joseph Fétis (1784-1871). 
Apart from writing the history of music, aspects of music theory during the 18th to 19th centuries can be traced to the work of important theorists. Jean-Philippe Rameau (1683 - 1764) in his Treatise on Harmony (1722) stated music is the science of sounds which divided into melody and harmony (Christensen,1993). The contributions of Joseph Sauveur (16531716) to define "the science of sound" in 1694 based on his deeply investigation about acoustics phenomenon (Maxham, 1976). Leonhard Euler is most often remembered for his theory of consonance. Published in 1739 as the Tentamen novae theoriae musicae which in English known as Attempt at a New Theory of music (Grant, 2013). Ernst Chladni (1756-1827) that earned his first measure of fame with Entdeckungen über die Theorie des Klanges in 1787 which known in English as a book on the theory of sound waves (Marvin, 2007). Hermann von Helmholtz (1821-1894) On the Sensations of Tone as a Physiological Basis for the Theory of Music which published in 1863 (Kursell, 2015). The above authors are motivated to provide many arguments for many aspects that have been thought to be associated with previously intangible music (Duckles, 1980).

However, the understanding of musical thought built by a number of theorists above prioritizes the cognitive aspect. The methodical disclosure of music as a phenomenon has not yet unified artistic and aesthetic aspects. Regarding the methodical aesthetic aspects of music, I am impressed with what Karnes (2016; p.26) wrote that, if we are to understand the radical transformations in musical thought that were accompanied by the institutionalization of musicology in the second half of the nineteenth century, we must begin at the start of that period, with a book that sparked a revolution in the learned discourse on the art. "Epochmaking," was the term used by the philosopher Robert Zimmermann as quoted by Karnes, (2016) to describe Hanslick's On the Musically Beautiful which is published in 1854. Eduard Hanslick (1825-1904) On the Musically Beautiful (Vom Musikalisch-Schönen) is pioneer a new and revolutionary approach to music study.

Hanslick argued that the disclosure of aesthetics in music needs to approach natural science methods. Hanslick's (current edition 2018; p. 1-2) in On the Musically Beautiful states:

Music alone along the arts still seems incapable of achieving this objective standpoint. Striving for as objective as scientific knowledge of things, of which the effects are being felt in all area of knowledge in our times, must necessarily also have an impact upon the investigation of beauty. System-building is giving way to research firmly based on the axiom that law of beauty proper to each particular art are inseparable from the distinctive characteristic of its material and its technique. The principle of that primary object of aesthetical investigation is the beautiful object, not the feeling of the subject

we found something interesting related to the discourse about musicology as the discipline in the romantic era. Hanslick's critical point of view on musical aesthetics rests on music structure. In defining aesthetics music, Hanslick argues that the nature of beauty in musical composition is independent and does not require any external content or extra musical idea. The beauty of music lies entirely in tone (Ton) as the most basic element of music (Bond, 2013, 2017). Hanslick's way of establishing an objective and scientific foundation for musical art is the same as isolating aesthetic understanding in music into an autonomous realm. This is very 
contradictory to the aesthetic tradition of music in the romantic era, as expressed by prioritizing emotional subjectivity (Yoshida, 2001).

Hamslic's opinion about his rejection of emotion in music was opposed by Wagner. As a composer and music critic of the romantic era, Wagner argues that the conception of music is based on the history of each work, whereby music and language, once indistinguishable, become increasingly specialized, with language voicing ideas, while music voicing emotions (Bonds, 2017).

Despite the debate with Wagner, Hamslict's passion to institutionalize music among academics has the support of his successor Guido Adler. Adler's 1885 article on "Umfang, Methode und Ziel der Musikwissenschaf" (scope, methods, and aim of music science) placed him among the earliest critics of music who voiced the methodological foundations of music (Breuer, 2011). Adler alienates aesthetic theory (Aesthetik der Tonkunst) into a "systematic discipline." Most importantly, Guido Adler reveals objectively verifiable "artistic laws" (Kunst Gesetze) that governs the evolution of musical forms and styles across different periods of history (Karnes, 2016).

Guido Adler's founding gesture - Musikwissenschaft, built music discipline as a system of scientific fields (taxonomy) oriented towards the (formative-educational) study of music as a type of thinking and practice. The views of Hamslict and Addler in the nineteenth century presented the emergence of "a new form of musical criticism, which is currently called as music analysis (Schmalfeldt, 2011).

The valuable view that I got about the history of music in the romantic era is that each works has its own objectivity and subjectivity. Musicology has important role to define objectives and subjective perspectives in music composition. Hamslict and Addler's mind encourages music to be understood in terms of the dialectic between universal and particular, collective and unique, schemes and deviations (Samson, 2014). Especially in the context of my study, it is objective and subjective features in classical music performance.

\section{The Performance Style in Romantic Era}

In comparing to music performance, music composition has a comprehensive approach to defining objective and subjective features in compositional work. However, the musicological approach to the previous composition has invited a lot of debate in the discourse of musical performances. The views related to objective and subjective features in music as thought by Hamslict and Addler are more focused on the area of music theory based on the existing composition.

Parncutt (2007) explicitly states that literary works that discuss the concept of systematic musicology in both German and English are often characterizations of musical works without an audience. In this sense, musicology functions as a renewal of scientific discourse in academic circles, but music is not studied for its own sake (Cook, 1992).

The growing division of artistic activity between composers and performers at the beginning of the 19th century, the score also became an ambiguity. On the one side, the composers claimed to be producing a permanent musical work found in this text, while the performers continued to interpret these texts as sounds with their own creation. The ambiguity over the 
control of the score was also an ambiguity over the role of the performer; should the performer be a creator or a re-creator (Bowen, 1993).

we agree with Bent's (1987) view that there are two justifications in understanding score in the nineteenth century, especially the romantic era, one is intentional, and the other is actual. However, the intentional aspect here boils down to an analysis of composition, musicology and philosophy. Some aspects that require attention in determining the style of performance in the side of performer have not been touched by theory in the romantic era. Even today, understanding the style of performance tends to be left on the instincts of each performer. Haynes (2007; p.166) asserts that most studies tend to look at the performance style from the point of view of the composer alone, this is undoubtedly a bias inherited from Romanticism.

Many features of the performance style in romantic period require a deeper understanding, especially related to expression features from performer's perspective. In the term of accentuation, Brown (2002) asserts that although accentuation is the most basic of the principal determinants of style in performance, but yet it is among the least thoroughly investigated and understood aspects of historical performing practice. In the term of legato and staccato, in 1801 Clementi published his opinion as quoted by Brown (2002) that without specific instruction, 'the composer leaves the legato and staccato to the performer's taste.

In the term of rubato, Kravitt (1973); Martin (2002) state that rubato is part of the expression of the Romantic era. Krafit classified the concept of rubato into rubato which only involves melody elements and rubato which involves all texture element. Martin (2002) corrected the concept of rubato proposed by Karvitt. She explained that rubato is apparently so complex musical phenomena that attempts to discuss and explain it often seem inadequate and resort to overly reductive categorizations. Furthermore, Martin (2002; p.95) asserts there is a natural tendency by musicologists to reduce rubato as complex musical phenomena to simplistic formulas.

The performer's perspective in classical music does not have a strong tradition as shown in music composition, musicology and philosophy of music. This is because the body of knowledge related to style of performance in the romantic era is sourced from secondary inquiry. There is the lack of references that explain the style of classical music performance from a performer's point of view. In this case, we agree with Martin (2002) that theorizing about complex musical performance practices does not mean eliminating actual practice.

There are many things in the notational symbolization of compositional works that cannot be generalized. The main factor is the meaning of signs and written instructions on compositional works varies from time to time, place to place and composer to composer (Brown, 2002; p.3). Both composers and performers each have their own characteristics, it is very reasonable in nature, therefore classical music performances always encourage variety and diversity of interpretations. On the one hand, the performer has responsibility is to embody an 'idea' that originated with the composer. On the other hand, the virtuoso performer could act as a magnet drawing the listener away from the notational of the compositional work towards the sound ambience of the performance. Virtuosity convey meaning. Great performers, no less than great composers (Samson, 2014) 
Kerman (1985); Taruskin (1997); Goehr (1992); Cook (1992) suggest that the discourse of classical music performances should encourage a paradigm shift from the concept of urtext (original text, as a musical score) to the concept of werktreue ('truth for the work'). In the concept of werktreue, the performer's interpretation in the composition work can be argued to be concepts and also a product of musical performances.

\section{Conclusion}

The history of music in the romantic era is not only related to the artistic form. In the term of extra-musical influence, the French revolution had a very big influence in inspiring monumental compositions in the romantic era. The history of music in the romantic era involved many aspects such as history of works, composers and performers; of traditions, media and styles; of institutions, ideas and responses. This causes compositional works born in the romantic era cannot be generalized.

In the romantic era, there is an awareness that instrumental music provides an unlimited platform of expression. musicologists and philosophers had a great interest in developing the meaning of instrumental music Musicology and philosophical perspectives have an important role in building knowledge structures in musical performances, especially in the subdisciplines of music theory, music composition, musical aesthetics and musicology.

The performer's perspective in classical music does not have a strong tradition as shown in music composition, musicology and philosophy of music. In the romantic era, understanding the style of performance from performer perspective is still limited to identifying the elements of music and has not yet established a concept-based method.

\section{Acknowledgements}

This article is part of an ongoing research with the title Artistic research: Characterization of my classical guitar sounds based on two selected repertoires. An article submitted in conformity with the requirements for the degree of Doctor of Philosophy in Music Performance Sultan Idris Education University Malaysia.

\section{Corresponding Author}

Herry Rizal Djahwasi

Department of Performing Arts Faculty of Music and Performing Arts Sultan Idris Education University 35900, Tanjung Malim, Perak, Malaysia

Email: herry@fmsp.upsi.edu.my

\section{Reference}

Beard, D., \& Gloag, K. (2016). Musicology: The key concepts. Routledge.

Bent, I., \& Drabkin, W. (1987). Analysis (New Grove Handbooks in Music). Palgrave Macmillan. Bonds, M. E. (2013). History of music in Western culture. Pearson.

Bonds, M. E. (2017). Absolute music: The history of an idea. Oxford University Press.

Borisovich, L. A., \& Anatolevich, K. V. (2016). Schopenhauer's philosophy of music as breakthrough from the world of rationality. International journal of humanities and social sciences, $1,725-730$.

Bowen, J. A. (1993), 'The Origins of the Ideology of Authenticity in Interpretation: Mendelssohn, Berlioz and Wagner as Conductors', a revised version of 'Mendelssohn, 
Berlioz, and Wagner as Conductors: The Origins of the Ideal of"Fidelity to the Composer'", Performance Practice Review, 6, pp. 77-88 [237-52]

Breuer, B. (2011). The Birth of musicology from the spirit of evolution: Ernst Haeckel's entwicklung lehrer as central component of Guido Adler's methodology for musicology. University of Pittsburgh.

Brown, C. (2002). Classical and romantic performing practice 1750-1900. Oxford University Press.

Burkholder, J. P., Grout, D. J., \& Palisca, C. V. (2019). A history of western music. W. W. Norton \& Company.

Christensen, T. (1993). Rameau and Musical Thought in the Enlightenment. Cambridge: Cambridge University Press.

Cook, N. (1992). A guide to musical analysis. W. W. Norton.

Duckles, V (1980) 'Musicology', The New Grove Dictionary of Music and Musicians, ed. Stanley Sadie (ed). Grove's Dictionaries of Music. London: Macmillan Publishers; Washington D.C.

Frisch, W. (2013). Music in the Nineteenth Century. W.W. Norton.

Goehr, L. (1992). The imaginary museum of musical works: An essay in the philosophy of music. Oxford University Press.

Gołąb Maciej. (2014). Twelve studies in Chopin: Style, aesthetics, and reception. Peter Lang Publishing Group.

Grant, R. M. (2013). Leonhard Euler's unfinished theory of Rhythm. Journal of Music Theory, 57(2), 245-286. https://doi.org/10.1215/00222909-2323479

Grove, G. (1896). Beethoven and his nine symphonies. London, Novello and company, Limited.

Haynes, B. (2007). The end of early Music: A Period Performer's history of music for the twentyfirst century. Oxford University Press.

Hanslick, E., \& Rothfarb, L. A. (2018). Eduard Hanslick's on the musically beautiful: A new translation. Oxford University Press.

Huneker, J. (1966). Chopin, the man and his music: With New Introduction., footnotes and index by Herbert Weinstock. Dover.

Marvin, U. B. (2007). Ernst Florens Friedrich Chladni (1756-1827) and the origins of modern meteorite research. Meteoritics \& Planetary Science, 42(S9). https://doi.org/10.1111/j.1945-5100.2007.tb00606.x

Maxham, R. E. (1976). The contributions of Joseph Sauveur (1653-1716) to acoustics.

Kamien, R. (2014). Music: An appreciation. McGraw-Hill Education.

Karnes, K. C. (2016). Music, criticism, and the challenge of history: Shaping modern musical thought in late nineteenth-century Vienna. Oxford University Press.

Kerman, J. (1985). Contemplating music challenges to musicology. Harvard University Press.

Kinderman, W. (2020). Beethoven: A political artist in revolutionary times. The University of Chicago Press.

Kravitt, E. F. (1973), 'Tempo as an Expressive Element in the Late Romantic Lied', Musical Quarterly, 59, pp. 497-518.

Kursell, J. (2015). A third note: Helmholtz, Palestrina, and the early history of musicology. Isis, 106(2), 353-366. https://doi.org/10.1086/682003

Martin, S. (2002), 'The Case of Compensating Rubato', Journal of the Royal Musical Association, 127, pp. 95-129.

Mckee, E. (2017). Dance and the music of Chopin: The Polonaise. In Bellman, J., \& Goldberg, H. (ed.). Chopin and his world. Princeton University Press. (pp.187-230). 
Parncutt, R. (2007). Systematic Musicology and the History and Future of Western Musical Scholarship. Journal of interdisciplinary music studies spring, Vol.1, 1, 1-32.

Rosen, C. (1971). The classical style Haydn, Mozart, Beethoven. Faber and Faber.

Salop, A. (1965). Intensity as a distinction between classical and romantic music. The Journal of Aesthetics and Art Criticism, 23(3), 359. https://doi.org/10.2307/428182

Sipe, T. (1998). Beethoven: Eroica symphony. Cambridge Music Handbooks. Cambridge University Press.

Samson, J. (2007). The Cambridge Companion to Chopin. Cambridge University Press.

Samson, J. (2014). The Cambridge History of nineteenth-Century music. Cambridge University Press.

Taruskin, R. (1997). Text and act: Essays on music and performance. Oxford University Press.

Thomas, A. (2007). Beyond the dance. In Samson, J. (ed.). The Cambridge Companion to Chopin. Cambridge University Press. (pp.145-159).

Schmalfeldt, J. (2011). In the Process of Becoming: Analytic and Philosophical Perspectives on Form in Early Nineteenth-Century Music. Oxford: Oxford University Press.

Schopenhauer, A. (1906). World as will \& idea. Kegan Paul.

Stevens, D. (1980). Musicology: a practical guide. London: Macdonald Futura.

Yoshida, H. (2001). Eduard Hanslick and the idea of "public" in musical culture: Towards a socio-political context of formalistic aesthetics. International Review of the Aesthetics and Sociology of Music, 32(2), 179. https://doi.org/10.2307/1562266 